\title{
ONE HUNDRED YEARS OF THE ANC: DEBATING LIBERATION HISTORIES TODAY
}

\author{
Arianna Lissoni, Jon Soske, Natasha Erlank, Noor \\ Nieftagodien and Omar Badsha (eds)
}

Johannesburg: Wits University Press

Cape Town: South African History Online

2012, 396 pages, index

ISBN 978-1-86814-573 7 (Paperback)

One hundred years of the ANC comprises a selection of papers by South African and international scholars read at a conference titled "One Hundred Years of the ANC: Debating Liberation Histories and Democracy Today" held at the University of the Witwatersrand in Johannesburg from 20 to 23 September 2011. The book commences with the two keynote addresses that framed the academic debate at the above-mentioned conference. The first, by Philip Bonner, addresses the topic "Fragmentation and cohesion in the ANC: The first 70 years". The second one, contributed by Joel Netshitenzhe, is entitled "A continuing search for identity: Carrying the burden of history". These keynote addresses are followed by an introductory chapter by the first three editors of the book and fourteen chronologically arranged chapters on various aspects of the ANC's hundred-year history. These fifteen chapters are:

- $\quad$ Chapter 1: One hundred years of the ANC: Debating struggle history after apartheid (Jon Soske, Arianna Lissoni and Natasha Erlank)

- Chapter 2: Religion and resistance in Natal, 1900-1910 (Norman Etherington)

- Chapter 3: Christianity and African nationalism in South Africa in the first half of the twentieth century (Natasha Erlank)

- $\quad$ Chapter 4: Charlotte Maxeke: A celebrated and neglected figure in history

Scientia Militaria, South African Journal of Military Studies, Vol 43, Nr 1, 2015, pp. 160-163. doi : $10.5787 / 42-1-1115$
(Thozama April)

- Chapter 5: Imagining the patriotic worker: The idea of 'decent work' in the ANC's political discourse (Franco Barchiesi) 
- Chapter 6: Popular movements, Contentious spaces and the ANC, 19431956 (Noor Nieftagodien)

- Chapter 7: Unravelling the 1947 'doctors' pact': Race, metonymy and the evasions of nationalist history (Jon Soske)

- $\quad$ Chapter 8: The politics of language and Chief Albert Luthuli's funeral, 30 July 1967 (Liz Gunner)

- Chapter 9: Robben Island University revisited (Crain Soudien)

- Chapter 10: Shishita: A crisis in the ANC in exile in Zambia, 1980-81 (Hugh Macmillan)

- Chapter 11: Comrade Mzwai (Vladimir Shubin)

- Chapter 12: Revisiting Sekhukhuneland: Trajectories of former UDF activists in post-apartheid South Africa (Ineke van Kessel)

- Chapter 13: Regeneration of ANC political power, from the 1994 electoral victory to the 2012 centenary (Susan Booysen)

- Chapter 14: The ANC: Party vanguard of the black middle class? (Roger Southall)

- Chapter 15: Globalisation, recolonisation and the paradox of liberation in Southern Africa (John S Saul)

As the titles of the various chapters indicate, this volume is not a systematic history of the ANC. The book seeks to open a debate "around controversial or obscured aspects of the ANC's century-long history ... [to] challenge the hegemonic narratives that have become an established part of South Africa's national discourse since 1994 ... [and] set out an agenda for future research" (see inside of front cover).

Exploring the history of the various 'fragments' of the ANC exposes the diverging local perspectives within the organisation, and offers a much better understanding of it than the master narrative, which the organisation has hammered into an indispensable political tool to brush out inconvenient aspects.

Joel Netshitenzhe, in the second keynote address, examines some of the key challenges that the ANC faces today with a view to its future survival and success against the background of its historical evolution. He argues, "survival and success are the product of a continuing search for identity and thus a healthy uncertainty". 1 He therefore condemns the current ANC leadership's sustained engulfment in electoral politics, which feeds a culture of self-interest, corruption and selfenrichment.

In their excellent introductory chapter, Soske, Lissoni and Erlank outline the nature and scope of the conference papers in general and those selected as chapters for this book. They regard the "contested, perhaps even fragile, character of nonracialism"2 and gender issues as two particularly significant conference themes. 
They hold that, since 1994, the ANC has by and large claimed centre stage for itself in the history of the liberation struggle with little acknowledgement of the contribution of rival political organisations and other role players. The current debate in this regard, the authors argue, indicates that there is a need for "a more complex understanding of the relationship between the ANC and other actors ... than the dichotomy between organisational narratives and the 'history from below' approach currently permits" ${ }^{3}$ in the history of the liberation struggle. Hence, this book seeks to "stimulate dialogue and debate across thematic and disciplinary boundaries ... [and] by moving away from the celebratory mode of the hundredth anniversary commemorations ... to engage with the relationship between the ... [ANC's] past [struggle history] and its present [as the ruling party haunted by notions of failure, corruption and controversy] in new and more critical ways, while raising a series of questions about the policies of producing historical knowledge"4 encompassing a wide variety of theoretical, methodological and political viewpoints.

The fourteen chronologically arranged chapters deal, from diverging perspectives, with four main topics, namely religion and nationalism (Chapters 2-4), questioning teleology (Chapters 5-8), exile and imprisonment (Chapters 9-11), and the ANC in power (Chapters 12-15). These very readable, thought-provoking chapters, like the conference they stemmed from, to some extent reflect "the predictable divisions between academic and activist, or defender and critic of the ruling party". 5 It is, however, exactly the diverging backgrounds, sentiments and approaches of the various authors that allow the book to provide a useful guide for revisiting and rewriting the history of the ANC within the national and international context from a rich variety of perspectives. The contributions of the various authors, contextualised by their personal environments and experiences, also bring home the extreme necessity for researchers to cast their nets widely to access a comprehensive collection of sources located in repositories across the globe.

Deon Visser

\section{Endnotes}

${ }^{1}$ Joel Netshitenzhe. "A continuing search for identity: Carrying the burden of history". In Arianna Lissoni, Jon Soske, Natasha Erlank, Noor Nieftagodien and Omar Badsha (eds), One Hundred Years of the ANC; Debating Liberation Histories Today. Johannesburg: Wits University Press and Cape Town South African History Online, 2012, 13-14.

2 Jon Soske, Arianna Lissoni and Natasha Erlank. "One hundred years of the ANC: Debating struggle history after apartheid". In Lissoni, Soske, Erlank, Nieftagodien and Badsha (eds), One Hundred Years of the ANC, 33. 
${ }^{3}$ Soske, Lissoni and Erlank. "One hundred years of the ANC: Debating struggle history after apartheid", 38.

${ }^{4}$ Soske, Lissoni and Erlank. "One hundred years of the ANC: Debating struggle history after apartheid", 49.

${ }^{5}$ Soske, Lissoni and Erlank. "One hundred years of the ANC: Debating struggle history after apartheid”, 31 . 